\title{
rSodC is a potential antigen to diagnose Corynebacterium pseudotuberculosis by enzyme-linked immunoassay
}

\author{
Antonio Pedro Fróes de Farias 1,2,3* ${ }^{1}$, José Tadeu Raynal Rocha Filho1, Silvana Beutinger Marchioro', \\ Luan Santana Moreira' , Andressa Souza Marques ${ }^{1}$, Maria da Conceição Aquino de Sá ${ }^{1}$, Antonio Anderson \\ dos Santos Oliveira', Maria Emília Alcântara' ${ }^{1}$, Ricardo Barros Mariutti ${ }^{4}$, Raghuvir Krishnaswamy Arni ${ }^{4}$, \\ Soraya Castro Trindade ${ }^{1,3}$ and Roberto Meyer ${ }^{1}$
}

\begin{abstract}
Caseous lymphadenitis $(\mathrm{CL})$ is a chronic infectious disease that affects sheep and goats. Many serological tests have been developed to detect the disease; one of the most widely used is the enzyme-linked immunosorbent assay (ELISA), due to its advantages, which include acceptable cost-effectiveness, applicability, sensitivity and specificity. ELISA formulations using recombinant proteins can exhibit significant sensitivity and specificity when using a single purified antigen. DTxR, Trx, TrxR, LexA, SodC, SpaC, NanH, and PknG recombinant proteins can be considered target proteins for ELISA development due to its extracellular or on the cell surface location, which allows a better recognition by the immune system. Therefore, the objectives of this study were to evaluate the antigenic reactivity of Corynebacterium pseudotuberculosis recombinant proteins in goat and sheep serum. Of eight proteins evaluated, rSodC was selected for validation assays with small ruminant serum samples from the semiarid region of the state of Bahia, Brazil. Validation assays with goat serum samples showed that ELISA-rSodC presented sensitivity and specificity of $96 \%$ and $94 \%$, respectively. Validation assays with sheep serum showed that ELISA-rSodC exhibited sensitivity and specificity of $95 \%$ and $98 \%$, respectively. Analysis of 756 field serum samples showed that rSodC identified 95 positive samples (23\%) in goats and 75 positive samples (21\%) in sheep. The ELISA with recombinant SodC protein developed in this study discriminated positive and negative serum samples with high levels of sensitivity and specificity. This formulation is promising for epidemiological surveys and $\mathrm{CL}$ control programs.
\end{abstract}

Trial registration AEC No 4958051018. 12/18/2018, retrospectively registered

Keywords: Caseous lymphadenitis, Corynebacterium pseudotuberculosis, ELISA, SodC recombinant protein

\section{Key points}

- rSodC protein was selected for diagnostic tests of sheep and goats.

- ELISA-rSodC showed high levels of sensitivity and specificity.

\footnotetext{
${ }^{*}$ Correspondence: froes_pedro@hotmail.com

${ }^{2}$ College of Science and Entrepreneurship (FACEMP), Santo Antônio de Jesus, BA, Brazil

Full list of author information is available at the end of the article
}

- Promising for epidemiological research and control of caseous lymphadenitis.

\section{Introduction}

Caseous lymphadenitis (CL) caused by the bacterium Corynebacterium pseudotuberculosis, is a chronic infectious disease that affects mainly sheep and goats. As the initial symptoms are not immediately noticeable, numerous serological tests have been developed to detect the infection in asymptomatic animals. The enzyme-linked 
immunosorbent assay (ELISA) is one of the most widely used due to its advantages of cost-effectiveness, applicability, sensitivity, and acceptable specificity (Menzies et al. 2004; Baird and Fontaine 2007; Oreiby 2015). Currently, there are no reliable tests available to diagnose all CL cases. ELISA, using several antigenic preparations, has already been tested (Sutherland et al. 1987; Menzies et al. 1994; Sting et al. 1998; Carminati et al. 2003); however, few formulations use recombinant proteins (Menzies et al. 1994; Rezende et al. 2016; Barral et al. 2019; Silva et al. 2019). This strategy could significantly increase sensitivity and specificity due to the use of a single purified antigen (Rezende et al. 2016).

The complete sequencing of the C. pseudotuberculosis genome, combined with the introduction of more advanced technologies, such as mass spectrometry, brought new perspectives to the study of proteins excreted by microorganisms as potential therapeutic, vaccine, or immunoassay targets (D'Afonseca et al. 2010; Bastos et al. 2012; Araújo et al. 2019). Some of the highlighted immunoassay and vaccine development target proteins include diptheric toxin repressor homologue (DTxR), Trx and TrxR thioredoxin complex proteins, LexA proteins, superoxide dismutase-C (SodC), SpaC, neuraminidase $\mathrm{H}(\mathrm{NanH})$, and $\mathrm{PknG}$ serine/threonine kinases Trost et al. 2010; Hall et al. 2011; Lin et al. 2016; SantanaJorge et al. 2016).

Diptheric toxin repressor homologue (DTxR) is responsible for regulating iron absorption and inhibiting diphtheria toxin synthesis in several species of the genus Corynebacterium (De Zoysa et al. 2005; Oliveira et al. 2017). The proteins of the Trx and TrxR thioredoxin complex detect and respond to oxidative stress generated by cell respiration, metabolism, and immune responses by host cells (Matsuzawa et al. 2017). The LexA protein is a key component of the SOS response, the main regulatory mechanism for DNA repair genes in many bacteria (Smollett et al. 2012).

SodC is an extracellular protein that protects the surface of C. pseudotuberculosis cells from the superoxide generated by mammalian host cells (Trost et al. 2010; SantanaJorge et al. 2016), while SpaC protein is recognized as an important virulence factor in bacterial adhesion to host tissues (SantanaJorge et al. 2016). The NanH protein belongs to an extracellular protein class that improves the recognition of sialic acids exposed on animal cell surfaces (Trost et al. 2010; Corrêa et al. 2018), and PknG is a protein possibly involved in glutamine metabolism and inhibition of phagolysosome formation (SantanaJorge et al. 2016).

Considering that the use of an efficient diagnostic method is crucial for the success of infectious disease control programs (Bastos et al. 2012; Rezende et al. 2016), and that extracellular or cell surface antigens allow for better recognition in ELISA tests (Oreiby 2015; Raynal et al. 2018), the objective of this study was to evaluate $C$. pseudotuberculosis rDTxR, rTrx, TrxR, rLexA, rNanH, rSodC, rPknG and rSpaC proteins to develop a CL diagnostic test using serum from naturally and experimentally infected goats and sheep.

\section{Materials and methods \\ Animal serum samples \\ Standardization}

Standardization of recombinant proteins (rDTxR, rTrx, rTrxR, rLexA, rNanH, rSodC, rPknG and rSpaC) was performed using 16 goat serum samples, ten positive samples from animals experimentally infected with $C$. pseudotuberculosis as confirmed by isolating bacteria from caseous lesions; and six negative serum samples from animals from CL nonendemic areas. ELISA-rSodC obtained the best results of sensitivity, specificity and differentiation of positive and negative samples in standardization, being selected for the later stages.

\section{Validation}

In the first validation step, recombinant SodC protein was selected to be tested with positive serum control samples from 50 goats and 45 sheep in which C. pseudotuberculosis infection was confirmed by isolating bacteria from caseous lesions. Samples from 50 goats and 45 sheep from CL nonendemic areas in southern Brazil, where there are strict controls for introducing new animals, were used as a negative control (Barral et al. 2019).

The second stage included 756 field samples of small ruminants from the semiarid region of the state of Bahia, Brazil, of which 400 were goat samples and 356 were sheep samples. All samples used had prior confirmation of the presence or absence of humoral response to C. pseudotuberculosis by indirect ELISA using bacterium secreted antigens (Carminati et al. 2003).

All procedures involving animals were performed according to the recommendations of the Animal Ethics Committee (AEC) of the Institute of Health Sciences, Federal University of Bahia, under protocol No. 4958051018.

\section{Antigenic evaluation of recombinant proteins Obtaining recombinant proteins}

The nucleotide sequences of the codon-optimized genes were deposited in the NCBI GenBanK BanKit with access numbers: LexA [MT918383]; Trx [MT918384]; TrxR [MT918385]; DTxR [MT918386]; NanH [MT918387]; SodC [MT918388]; PknG [MT918389]; SpaC [MT918390]. 
The rDTxR, rTrx, rTrxR, and rLexA recombinant proteins used in this study were kindly provided by the Multiuser Center for Biomolecular Innovation, IBILCE/ UNESP, São José do Rio Preto, SP, Brazil. These proteins were produced and synthesized as described by Kabsch (2010).

The genes coding for C. pseudotuberculosis SodC, $\mathrm{SpaC}, \mathrm{NanH}$, and PknG proteins were synthesized and cloned individually in the commercial vector pD444-NH (DNA 2.0 Inc., USA) (https://www.atum.bio), with the original codons replaced by Escherichia coli-optimized codons. The recombinant plasmids were transformed into E. coli BL21 (DE3) Star and purified using affinity chromatography, as previously described (Simionatto et al. 2010). Fractions containing recombinant proteins were identified using sodium dodecyl sulfate polyacrylamide gel electrophoresis (SDS-PAGE) and quantified using the Lowry protein assay (Bio-Rad Laboratories, CA, USA) and following the manufacturer's instructions.

\section{Indirect ELISA standardization using recombinant proteins}

A checkerboard procedure with different antigen concentrations, serum sample dilutions, and anti-IgG goat and sheep antigens tested in combination was used to screen recombinant antigens and standardize ELISA. 96-well polystyrene plates (GREINER Bio-One, São Paulo, Brazil) were sensitized with $100 \mu \mathrm{L}$ of each of the recombinant proteins (at concentrations of 0.1, 0.5, 1.0, and $2.0 \mu \mathrm{g} / \mathrm{mL}$ ), diluted in $0.05 \mathrm{M}$ carbonate/bicarbonate buffer (pH 9.6), and incubated at $4{ }^{\circ} \mathrm{C}$ for $16 \mathrm{~h}$. The plates were washed with $0.01 \mathrm{M}$ PBS, $0.05 \%$ Tween 20 (PBS-T) and blocked with $200 \mu \mathrm{L}$ of casein (5\%) per well for two h. After washing with PBS-T, $50 \mu \mathrm{L} /$ well of control sera (positive and negative) were added at 1:50, 1:100, and 1:200 dilutions in PBS-T containing 1\% casein, and incubated at $37{ }^{\circ} \mathrm{C}$ for one $\mathrm{h}$. After being washed five more times, $50 \mu \mathrm{L} /$ well of the anti-IgG goat or sheep antibody conjugated with peroxidase (Bethyl, Montgomery, USA) was added at dilutions of 1:5,000, 1:10,000, 1:20,000, and 1:30,000 in PBS-T containing 1\% casein, and incubated at $37^{\circ} \mathrm{C}$ for $45 \mathrm{~min}$. Color development was performed with the addition of $50 \mu \mathrm{L} /$ well of 1:2-O-phenylenediamine substrate (OPD) (Sigma-Aldrich, St. Louis, USA) at $22^{\circ} \mathrm{C}$, away from light, for $20 \mathrm{~min}$. The reaction was arrested by adding $25 \mu \mathrm{L} /$ well of $4 \mathrm{~N} \mathrm{H}_{2} \mathrm{SO}_{4}$. The mean optical density (OD) at $492 \mathrm{~nm}$ was determined using a microtiter plate reader (THERMO PLACA, Miami, USA).

The interplate OD was corrected for each standardized ELISA mode by multiplying the correction factor (FtC) between plates by the OD reading (Zwirner 1996). The corrected OD (cD) was calculated using the following formula: $\mathrm{FtC}=$ mean $\mathrm{OD}$ of the standard positive of the reference plate /Mean OD of the standard positive of each plate. Therefore, $\mathrm{cD}=\mathrm{OD} \times \mathrm{FtC}$.

\section{ELISA validation with recombinant SodC protein}

After identifying the optimal antigen concentration $(0.1 \mu \mathrm{g} / \mathrm{mL})$, serum dilutions (1:100) and goat and sheep secondary antibodies $(1: 20,000)$, recombinant SodC protein was selected to validate the ELISA using goat and sheep sera. The ELISA was used with antigens secreted from C. pseudotuberculosis, as standardized by Carminati et al. (2003) for comparison. Serum samples were considered positive when the reaction exhibited an $\mathrm{OD}>$ mean plus two OD standard deviations obtained for negative controls (Patarroyo et al. 2002).

\section{Statistical analysis}

To evaluate the specificity, sensitivity, and cut-off point of the ELISA immunoassay, the data obtained were analyzed using the Receiver Operating Characteristic (ROC). SPSS software v.23 for Windows was used for statistical analysis. The graphics were generated through the GrapfPad Prism 8 and Microsoft office 2013 package.

\section{Results}

\section{Recombinant protein expression and purification}

The recombinant proteins expressed in E. coli resulted in yields of $1.44 \mathrm{mg} / \mathrm{mL}(\mathrm{rSodC}), 1.0 \mathrm{mg} / \mathrm{mL}(\mathrm{rPknG})$, $0.5 \mathrm{mg} / \mathrm{mL}$ (rSpaC), and $0.75 \mathrm{mg} / \mathrm{mL}(\mathrm{rNanH})$. All recombinant proteins were expressed as insoluble, and were purified under denaturing conditions in $8 \mathrm{M}$ urea. The rDTxR, rTrx, rTrxR, and rLexA recombinant proteins showed yields of $0.55 \mathrm{mg} / \mathrm{mL}, 1.3 \mathrm{mg} / \mathrm{mL}, 1.5 \mathrm{mg} /$ $\mathrm{mL}$, and $2.0 \mathrm{mg} / \mathrm{mL}$, respectively. SDS-PAGE (Fig. 1) was

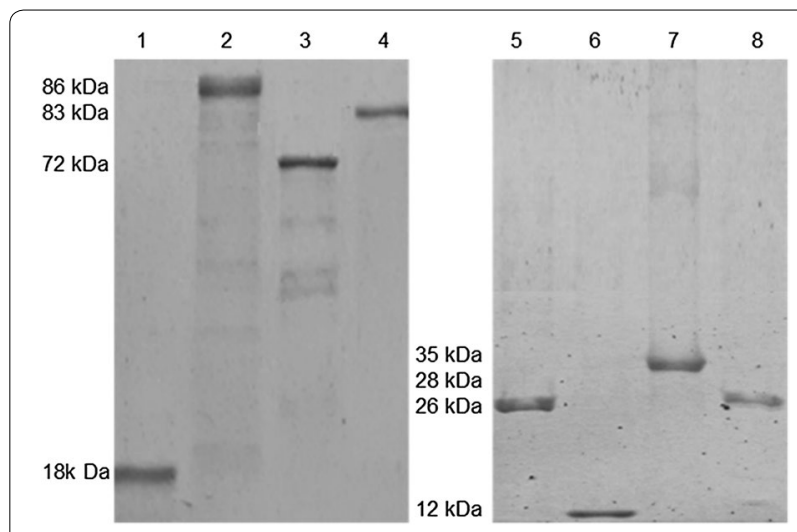

Fig. 1 12\% SDS-PAGE gel stained with Coomassie blue to show the identification and purification of recombinant proteins. 1-SodC (18 kDa); 2-SpaC (86 kDa); 3-NanH (72 kDa); 4-PknG (83 kDa); 5-DTxR (26 kDa); 6-Trx (12 kDa); 7-TrxR (35 kDa); 8-LexA (28 kDa) 
Table 1 The ratio of OD, serum dilution and conjugated protein values using serum of infected and noninfected goats in indirect checkerboard ELISA using $C$. pseudotuberculosis rDTxR, rTrx, rTrxR, rLexA, rNanH, rSodC, rPknG, and rSpaC recombinant protein as antigens. Pos/neg OD-ratio between positive and negative serum optical density values

\begin{tabular}{lllll}
\hline Proteins & $\begin{array}{l}\text { Pos/ } \\
\text { neg OD } \\
\text { ratio }\end{array}$ & $\begin{array}{l}\text { Serum } \\
\text { dilution }\end{array}$ & $\begin{array}{l}\text { Anti-lgG } \\
\text { dilution }\end{array}$ & $\begin{array}{l}\text { Concentration } \\
\left(\boldsymbol{\mu} \mathbf{g} / \mathbf{m L}^{-1}\right)\end{array}$ \\
\hline rDTxR & 6.5 & $1: 100$ & $1: 20.000$ & 0.1 \\
rTrx & 6.0 & & & 0.1 \\
rTrXR & 7.3 & & 0.5 \\
rLexA & 5.3 & & 0.1 \\
rNanH & 5.4 & & 0.5 \\
rSodC & 9.0 & & 0.1 \\
rPknG & 3.8 & & 1 \\
rSpaC & 1.2 & & & 0.5 \\
\hline
\end{tabular}

Table 2 Cut-off values, sensitivity, and specificity of $C$. pseudotuberculosis rDTxR, rTrx, rTrxR, rLexA, rNanH, rSodC, rPknG, and rSpaC proteins obtained through ROC curve analysis with indirect ELISA results using positive and negative control sera

\begin{tabular}{llcc}
\hline Proteins & Cut-off & Sensitivity (\%) & Specificity (\%) \\
\hline rDTxR & 0.272 & 70 & 67 \\
rTrx & 0.336 & 90 & 50 \\
rTrxR & 0.224 & 90 & 83 \\
rLexA & 0.162 & 70 & 50 \\
rNanH & 0.186 & 70 & 67 \\
rSodC & 0.275 & 100 & 100 \\
rPknG & 0.243 & 94 & 97 \\
rSpaC & 0.162 & 60 & 33 \\
\hline
\end{tabular}

used to evaluate the purity of the recombinant proteins used in this study.

\section{Determination of antigenic potential to screen recombinant proteins}

The results obtained for each of the recombinant proteins are shown in Table 1. The highest positive/negative ratio coefficient (9.0) was obtained with rSodC protein at $0.1 \mu \mathrm{g} / \mathrm{mL}$ using serum diluted to $1: 100$ and secondary antibody at 1:20,000.

The results of the ROC curve analysis are presented in Table 2. Only tests performed with rSodC and $\mathrm{rPknG}$ proteins showed sensitivity and specificity values $>90 \%$. Although it has high sensitivity (94\%) and specificity (97\%), rPknG was not chosen for the validation tests due to its low ratio of positive and negative sera (ratio $=3.8$ ) (Table 1). The best sensitivity and specificity values were found for rSodC protein (100\% for both), and thus it was selected for validation studies with a greater number of serum samples.

\section{ELISA validation test with recombinant SodC protein}

The rSodC protein was selected for ELISA validation, with a higher number of goat and sheep serum samples previously characterized. Samples from 50 goats and 45 sheep naturally infected were used as positive controls, and samples from 50 goats and 45 sheep from CL nonendemic areas were used as negative controls. The results comparing the ELISA using the recombinant proteins with indirect ELISA using secreted C. pseudotuberculosis antigens (Secreted Ag.), are shown in Table 3; Fig. 2.

The rSodC protein ELISA differentiated infected from noninfected animals, with sensitivity and specificity levels of $96 \%$ and $94 \%$, respectively, for goat samples. These values were similar to those found in testing using secreted C. pseudotuberculosis antigens: 100\% and 96\% sensitivity and specificity, respectively. The standardized rSodC protein ELISA validation with sheep serum

Table 3 Validation parameters for indirect ELISA using positive and negative control serum samples from goats and sheep. rSodC protein and secreted C. pseudotuberculosis antigens were used as test antigens

\begin{tabular}{|c|c|c|c|c|}
\hline \multirow[t]{2}{*}{ Parameter } & \multicolumn{2}{|l|}{ Goat } & \multicolumn{2}{|l|}{ Sheep } \\
\hline & rSodC & Secreted antigen & rSodC & Secreted antigen \\
\hline Positive control & 50 & 50 & 45 & 45 \\
\hline Negative control & 50 & 50 & 45 & 45 \\
\hline Cut-off & 0.275 & 0.274 & 0.332 & 0.510 \\
\hline Sensitivity (\%) & 96 & 100 & 95 & 98 \\
\hline Specificity (\%) & 94 & 96 & 98 & 93 \\
\hline Accuracy (\%) & 97.6 & 99.8 & 98.9 & 99.5 \\
\hline Positive predictive value (\%) & 100 & 100 & 100 & 100 \\
\hline Negative predictive value (\%) & 93.7 & 99.5 & 97.1 & 98.7 \\
\hline
\end{tabular}



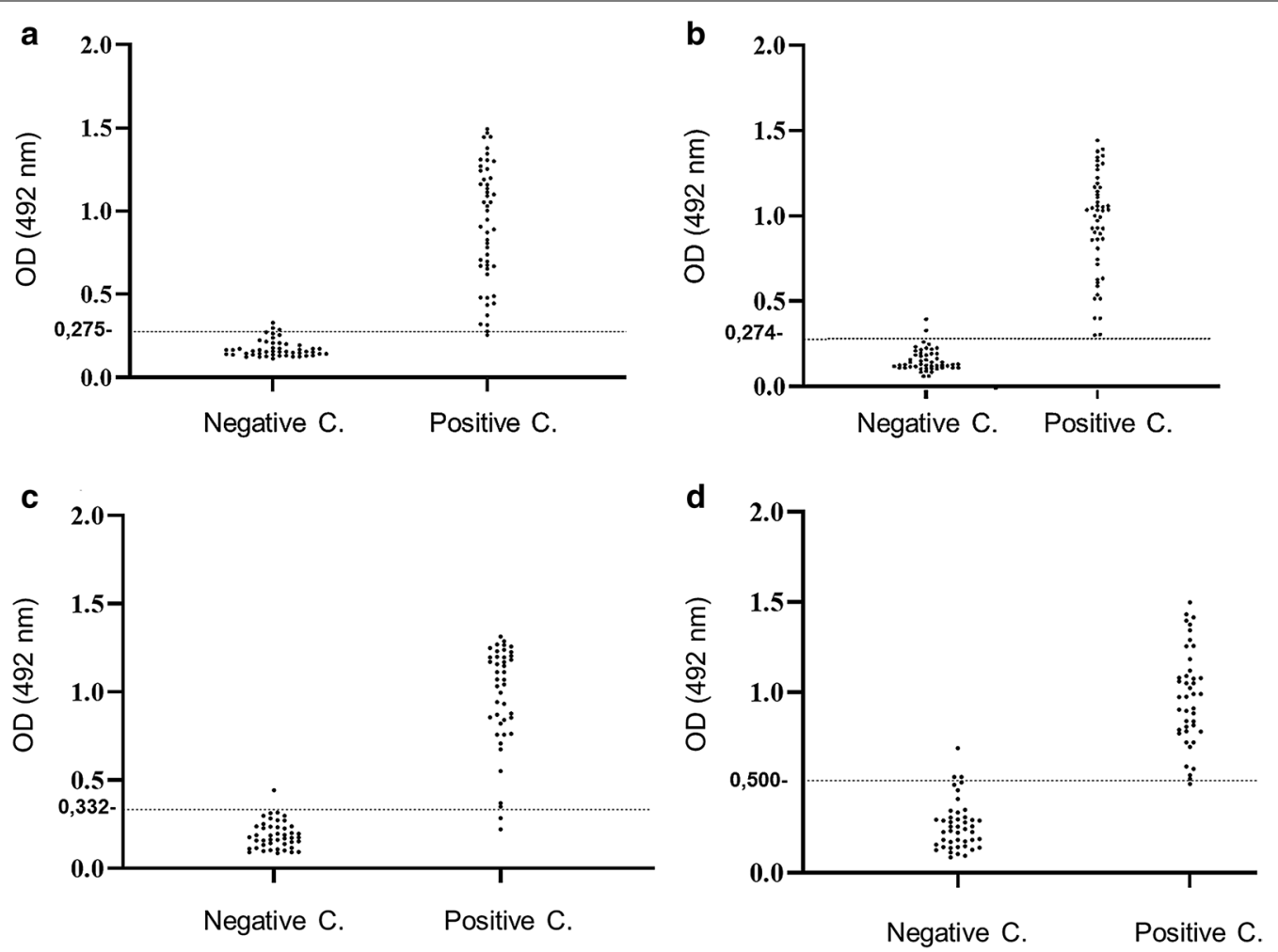

Fig. 2 Distribution of OD results from negative and positive control serum samples evaluated by ELISA using rSodC protein antigens and secreted C. pseudotuberculosis antigens. a ELISA-rSodC with goat sera, b ELISA-secreted C. pseudotuberculosis antigens with goat sera, c ELISA-rSodC with sheep sera and $\mathbf{d}$ ELISA-secreted C. pseudotuberculosis antigens with sheep sera. The graphs show the OD values obtained for each positive or negative sample. The lines in the graphs represent the cut-off value for each test

exhibited sensitivity and specificity of $95 \%$ and $98 \%$, respectively, and in tests using secreted antigens, the sensitivity, and specificity were $98 \%$ and $93 \%$, respectively.

In the rSodC protein assay, there were two false-positive results (negative samples with OD above the cut-off point) for goats and one for sheep. As for false-negative results (positive control serum with $O D$ values below the cut-off point), there was one sample for goats and two for sheep. Using the same samples against secreted C. pseudotuberculosis antigens, there were two false-positive results for goats, three false-positive results for sheep, and only one false-negative result for sheep.

\section{Use of the rSodC ELISA in field samples}

The ELISA-rSodC was performed using 400 serum sample from goats and 356 from sheep collected in field conditions. The cut-off point was defined by the ROC curve. The results are presented in Fig. 3.

In the ELISA with goat samples, rSodC protein was recognized in the serum of 95 positive samples from the 400 samples evaluated (23\%), while the antigen secretion test detected 83 positive samples (20\%). For sheep samples, the rSodC protein was recognized in 75 positive samples out of 356 evaluated specimens (21\%), while secreted antigens yielded 35 positive results (10\%).

\section{Discussion}

In the present study, the standardized test using rSodC protein showed satisfactory performance in the identification of positive and negative cases of C. pseudotuberculosis by serological responses, both in the initial standardization tests and in validation tests with goat and sheep samples. The use of this protein as an antigen to diagnose CL is promising due to the observed high sensitivity and specificity values, which were comparable or superior to those described in the literature to detect goats and sheep infected with C. pseudotuberculosis using different recombinant antigenic preparations (Menzies et al. 2004; Rezende et al. 2016; Barral et al. 2019).

Sensitivity and specificity are important factors that must be considered when selecting one or more diagnostic tests for a screening program. Serological tests must have sensitivity and specificity $>90 \%$ to eliminate CL infections in large batches (O'Reilly et al. 2010). A test of lower specificity may lead to false-positive results, and 

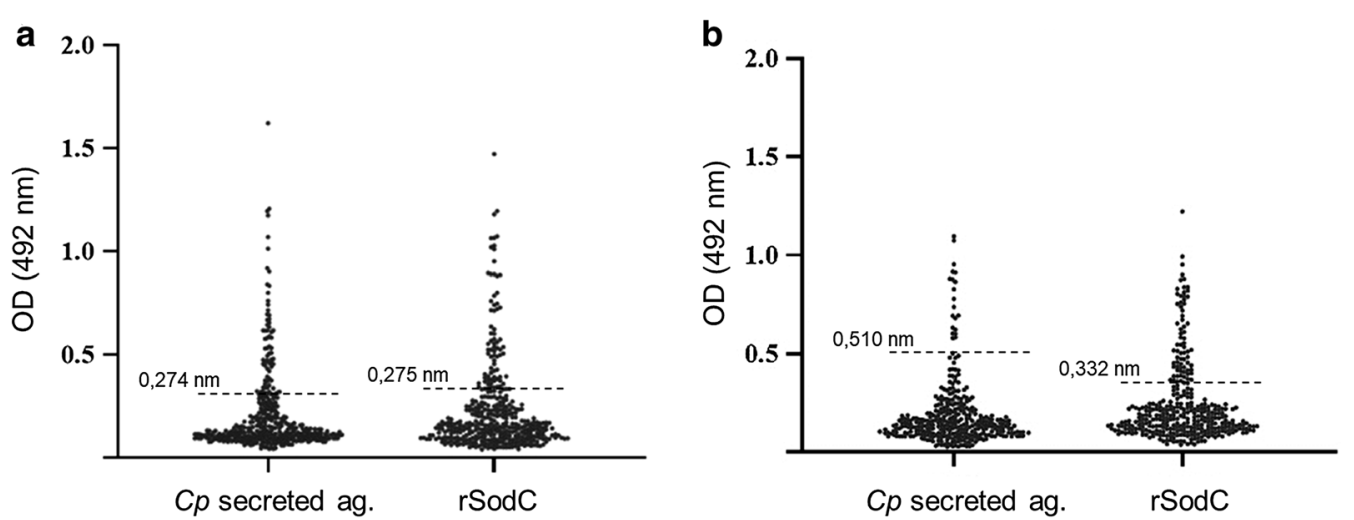

Fig. 3 Distribution of OD results using rSodC protein and secreted C. pseudotuberculosis antigen from goat (a) and sheep (b) field samples. The graphs show the OD values obtained for each goat and sheep sample evaluated. The lines in the graphs represent the cut-off value for each test

decreased sensitivity may result in false-negatives (Carminati et al. 2003; Bastos et al. 2012).

The use of rSodC protein presents better ELISA reproducibility conditions when compared to secreted antigens due to greater standardization of antigenic composition. This characteristic is relevant for large-scale testing. As they are purified antigens, recombinant proteins can improve specificity, reducing the chances of cross reactions with molecules of other microorganisms. They can also influence sensitivity, since the amount of immunodominant protein used to sensitize the plaques is greater than the concentration of this molecule in a raw antigen extract (Barral et al. 2019).

For seven (rDTxR, rTrx, rTrxR, rLexA, rNanH, rPknG, and $\mathrm{rSpaC}$ ) other recombinant proteins of $C$. pseudotuberculosis were evaluated in ELISA, however lower sensitivity and/or specificity were obtained, and were unable to satisfactorily discriminate samples from infected and noninfected animals. These proteins play important roles in the survival of these microorganisms, and have been evaluated in silico and in vitro to determine the potential of these recombinant constructs as therapeutic targets (Resende et al. 2011; Olson et al. 2013; Lin et al. 2016). However, although they were previously indicated as promising (SantanaJorge et al. 2016), their performance was not confirmed in studies involving animal serum evaluation. The high level of conservation of these proteins in eukaryotes and prokaryotes (Hall et al. 2011) may be the main factor contributing to this performance.

The selection of recombinant antigens for validation tests in the present study was based on standardization with goat serum. The rSodC protein yielded better sensitivity and specificity results. Based on these observations, the conditions used for validation tests in goats were extrapolated for analyses with sheep samples, since the pathogenesis and immune response to the disease caused by C. pseudotuberculosis is similar for these animal models.

ELISA is the most widely used serological test to detect C. pseudotuberculosis serum status due to its high cost-effectiveness and applicability (Oreiby 2015). Few methods use recombinant proteins to diagnose $C L$, which can provide significant specificity and sensitivity levels by using a single purified antigen (Rezende et al. 2016). Efforts to characterize the bacterial proteome and to discover new secreted antigens with potential for use in vaccine development and immunoassays against C. pseudotuberculosis infection are being made (Raynal et al. 2018). Thus, the good performance of the ELISA test using rSodC protein demonstrated that it is promising for epidemiological research and CL control programs due to its accuracy in detecting goats and sheep infected with $C$. pseudotuberculosis.

\section{Acknowledgements}

The authors thank the Bahia Research Support Foundation (FAPESB) for financial contribution with the APFF PhD grant, and the Multiuser Center for Biomolecular Innovation, IBILCE/UNESP, São José do Rio Preto, SP, Brazil, for the synthesis of the recombinant proteins.

\section{Authors' contributions}

SBM, JTRRF and RM conceived and designed the research. APFF, LM, ASM, AASO and MCAS carried out the experimentation. RBM and RKA provided the recombinant proteins. MEA contributed analytical tools. APFF, SBM, JTRRF, SCT and RM participated of the elaboration of manuscript. All authors read and approved the final manuscript.

Funding

Not applicable.

Availability of data and materials

The data of this work are available at: http://www.labimuno.ufba.br/.

Code availability

Not applicable. 


\section{Ethics approval and consent to participate}

All applicable national and institutional guidelines for the care and use of animals were followed. All procedures involving animals were performed according to the recommendations of the Animal Ethics Committee (AEC) of the Institute of Health Sciences, Federal University of Bahia, under protocol No. 4958051018. This article does not contain any studies with human participants performed by any of the authors.

\section{Consent to participate}

Declare that all the researchers cited in this manuscript have consented to the participation in the work.

\section{Competing interests}

The authors declare that they have no competing interests.

\section{Author details}

${ }^{1}$ Immunology and Molecular Biology Laboratory (LABIMUNO), Federal University of Bahia (UFBA), Salvador, BA, Brazil. ${ }^{2}$ College of Science and Entrepreneurship (FACEMP), Santo Antônio de Jesus, BA, Brazil. ${ }^{3}$ Feira de Santana State University (UEFS), Feira de Santana, BA, Brazil. ${ }^{4}$ Multiuser Center for Biomolecular Innovation (IBILCE/UNESP), São José do Rio Preto, SP, Brazil.

Received: 7 August 2020 Accepted: 10 October 2020

Published online: 19 October 2020

\section{References}

Araújo CL, Alves J, Nogueira W, Pereira LC, Gomide AC, Ramos R, Azevedo V, Silva A, Folador A (2019) Prediction of new vaccine targets in the core genome of Corynebacterium pseudotuberculosis through omics approaches and reverse vaccinology. Gene 702:36-45. https://doi. org/10.1016/j.gene.2019.03.049

Baird GJ, Fontaine MC (2007) Corynebacterium pseudotuberculosis and its role in ovine caseous lymphadenitis. J Comp Path 37:179-210. https://doi. org/10.1016/j.jcpa.2007.07.002

Barral TD, Mariutti RB, Arni RK, Santos AJ, Loureiro D, Sokolonski AR, Azevedo V, Borsuk S, Meyer R, Portela RD (2019) A panel of recombinant proteins for the serodiagnosis of caseous lymphadenitis in goats and sheep. Microb Biotechnol 0(0):1-11. https://doi.org/10.1111/1751-7915.13454

Bastos BL, Portela RWD, Dorella FA, Ribeiro D, Seyffert N, Castro TLP, Miyoshi A, Oliveira SC, Meyer R, Azevedo V (2012) Corynebacterium pseudotuberculosis: immunological responses in animal models and zoonotic potential. Clin Cell Immunol 4(5):1-15. https://doi.org/10.4172/2155-9899.S4-005

Carminati R, Bahia R, Moura-Costa LF, Paule BJA, Vale VL, Regis L, Freire SM, Nascimento I, Schaer R, Meyer R (2003) Determinação da sensibilidade e da especificidade de um teste de ELISA indireto para o diagnóstico de linfadenite caseosa em caprinos. R Ci Méd Biol 2(1):88-93. https://doi. org/10.9771/cmbio.v2i1.4256

Corrêa Jl, Stocker A, Trindade SC, Vale V, Brito T, Bastos B, Raynal JT, Miranda PM, Alcantara AC, Freire SM, Moura-Costa L, Meyer R (2018) In vivo and in vitro expression of five genes involved in Corynebacterium pseudotuberculosis virulence. AMB Expr 8(89):1-9. https://doi.org/10.1186/s1356 8-018-0598-z

D'Afonseca V, Prosdocimi F, Dorella FA, Pacheco LGC, Moraes PM, Pena I, Ortega JM, Teixeira S, Oliveira SC, Coser EM, Oliveira LM, Oliveira GC, Meyer R, Miyoshi A, Azevedo V (2010) Survey of genome organization and gene content of Corynebacterium pseudotuberculosis.. Microbiol Res 165(4):312-320. https://doi.org/10.1016/j.micres.2009.05.009

De Zoysa A, Efstratiou A, Hawkey PM (2005) Molecular characterization of diphtheria toxin repressor (DTxR) genes present in nontoxigenic Corynebacterium diphtheriae strains isolated in the United Kingdom. J Clin Microbiol 43(1):223-228. https://doi.org/10.1128/JCM.43.1.223-228.2005

Hall G, Bradshaw TD, Laughton CA, Stevens MF, Emsley J (2011) Structure of Mycobacterium tuberculosis thioredoxin in complex with quinol inhibitor PMX464. Protein Sci 20:210-215. https://doi.org/10.1002/pro.533

Kabsch W (2010) XDS. Acta Crystallogr D Struct Biol 66:125-132. https://doi. org/10.1107/S0907444909047337

Lin K, O'Brien KM, Trujillo C, Wang R, Wallach JB, Schnappinger D, Ehrt S (2016) Mycobacterium tuberculosis thioredoxin reductase is essential for thiol redox homeostasis but plays a minor role in antioxidant defense. PLoS Pathog 12(6):1-20. https://doi.org/10.1371/journal.ppat.1005675

Matsuzawa A (2017) Thioredoxin and redox signaling: roles of the thioredoxin system in control of cell fate. Arch Biochem Biophys 617:101-105. https:// doi.org/10.1016/j.abb.2016.09.011

Menzies PI, Hwang YT, Prescott JF (2004) Comparison of an interferon-gamma to a phospholipase D enzyme-linked immunosorbent assay for diagnosis of Corynebacterium pseudotuberculosis infection in experimentally infected goats. Vet Microbiol 100:129-137. https://doi.org/10.1016/j. vetmic.2004.01.012

Menzies PI, Muckle CA, Hwang YT, Songer JG (1994) Evaluation of an enzyme-linked immunosorbent assay using an Escherichia coli recombinant phospholipase D antigen for the diagnosis of Corynebacterium pseudotuberculosis infection. Small Rumin Res 13:193-198. https://doi. org/10.1016/0921-4488(94)90096-5

Oliveira A, Oliveira LC, Aburjaile F, Benevides L, Tiwari S, Jamal SB, Silva A, Figueiredo HCP, Ghosh P, Portela RW, Azevedo VAC, Wattam AR (2017) Insight of genus Corynebacterium: ascertaining the role of pathogenic and non-pathogenic species. Front Microbiol 8:1-18. https://doi.org/10.3389/ fmicb.2017.01937

Olson AL, Neumann TS, Cai S, Sem DS (2013) Solution structures of Mycobacterium tuberculosis thioredoxin $\mathrm{C}$ and models of the intact thioredoxin system suggest new approaches to inhibitor and drug design. Proteins 81(4):675-689. https://doi.org/10.1002/prot.24228

Oreiby AF (2015) Diagnosis of caseous lymphadenitis in sheep and goat. Small Rumin Res 123:160-166. https://doi.org/10.1016/j.smallrumre s.2014.11.013

O'Reilly KM, Medley GF, Green LE (2010) The control of Corynebacterium pseudotuberculosis infection in sheep flocks: a mathematical model of the impact of vaccination, serological testing, clinical examination and lancing of abscesses. Prev Vet Med 95:115-126. https://doi.org/10.1016/j. prevetmed.2010.02.012

Patarroyo JH, Portela RW, De Castro RO, Pimentel JC, Guzman F, Patarroyo ME, Vargas MI, Prates AA, Dias Mendes MA (2002) Immunization of cattle with synthetic peptides derived from the Boophilus microplus gut protein (Bm86). Vet Immunol Immunopathol 88:163-172. https://doi. org/10.1016/s0165-2427(02)00154-X

Raynal JT, Bastos BL, VilasBoas PCB, Sousa TJ, CostaSilva M, Sá MCA, Portela RW, MouraCosta LF, Azevedo V, Meyer R (2018) Identification of membraneassociated proteins with pathogenic potential expressed by Corynebacterium pseudotuberculosis grown in animal serum. BMC Res Notes 11(73):1-6. https://doi.org/10.1186/s13104-018-3180-5

Resende BC, Rebelato AB, D'Afonseca V, Santos AR, Stutzman T, Azevedo VA, Santos LL, Miyoshi A, Lopes DO (2011) DNA repair in Corynebacterium model. Gene 482:1-7. https://doi.org/10.1016/j.gene.2011.03.008

Rezende AFS, Brum AA, Reis CG, Angelo HR, Leal KS, Silva MTO, Simionatto S, Azevedo V, Santos A, Portela RW, Dellagostin O, Borsuk S (2016) In silico identification of Corynebacterium pseudotuberculosis antigenic targets and application in immunodiagnosis. J Med Microbiol 65:521-529. https ://doi.org/10.1099/jmm.0.000263

SantanaJorge KTO, Santos TM, Tartaglia NR, Aguiar EL, Souza RFS, Mariutti RB, Eberle RJ, Arni RK, Portela RW, Meyer R, Azevedo V (2016) Putative virulence factors of Corynebacterium pseudotuberculosis FRC41: vaccine potential and protein expression. Microb Cell Fact 15(83):1-13. https:// doi.org/10.1186/s12934-016-0479-6

Simionatto S, Marchioro SB, Galli V, Hartwig DD, Carlessi RM, Munari FM, Laurino JP, Conceição FR, Dellagostin OA (2010) Cloning and purification of recombinant proteins of Mycoplasma hyopneumoniae expressed in Escherichia coli. Protein Expr Purif 69:132-136. https://doi.org/10.1016/j. pep.2009.09.001

Silva MTO, Bezerra FSB, Pinho RB, Ferreira CS, Vivas WL, Portela RWD, Azevedo VAC, Borsuk S (2019) The combination of Corynebacterium pseudotuberculosis recombinant proteins rPLD, rCP01850 and rCP09720 for improved detection of caseous lymphadenitis in sheep by ELISA. J Med Microbiol 68:1759-1765. https://doi.org/10.1099/jmm.0.001096

Smollett KL, Smith KM, Kahramanoglou C, Arnvig KB, Buxton RS, Davis EO (2012) Global analysis of the regulon of the transcriptional repressor LexA, a key component of the SOS response in Mycobacterium tuberculosis. J Biol Chem 287(26):1-19. https://doi.org/10.1074/jbc.M112.357715

Sting R, Steng G, Spengler D (1998) Serological studies on Corynebacterium pseudotuberculosis infections in goats using 
enzyme-linked immunosorbent assay. J Vet Med 45:209-216. https://doi. org/10.1111/j.1439-0450.1998.tb00785.x

Sutherland SS, Ellis TM, Mercy AR, Paton M, Middleton H (1987) Evaluation of an enzyme-linked immunosorbent assay for the detection of Corynebacterium pseudotuberculosis infection in sheep. Aust Vet J 64(9):263-266. https://doi.org/10.1111/j.1751-0813.1987.tb15953.x

Trost E, Ott L, Schneider J, Schröder J, Jaenicke S, Goesmann A, Husemann P, Stoye J, Dorella FA, Rocha FS, Soares SC, D'Afonseca V, Miyoshi A, Ruiz J, Silva A, Azevedo V, Burkovski A, Guiso N, Join-Lambert OF, Kayal S, Tauch A (2010) The complete genome sequence of Corynebacterium pseudotuberculosis FRC41 isolated from a 12-year-old girl with necrotizing lymphadenitis reveals insights into gene-regulatory networks contributing to virulence. BMC Genom 11(728):1-17. https://doi.org/10.1186/14712164-11-728 doi

Zwirner NW (1996) Elisa. In: Margni RA (ed) Imunologia e Imunoquímica, 5rd edn. Panamericana, Buenos Aires, pp 798-820

\section{Publisher's Note}

Springer Nature remains neutral with regard to jurisdictional claims in published maps and institutional affiliations.

\section{Submit your manuscript to a SpringerOpen ${ }^{\circ}$ journal and benefit from:}

- Convenient online submission

- Rigorous peer review

- Open access: articles freely available online

- High visibility within the field

- Retaining the copyright to your article

Submit your next manuscript at $\boldsymbol{\nabla}$ springeropen.com 